\title{
Climate change and prolongation of growing season: changes in regional potential for field crop production in Finland
}

\author{
Pirjo Peltonen-Sainio ${ }^{1}$, Lauri Jauhiainen ${ }^{2}$, Kaija Hakala ${ }^{1}$ and Hannu Ojanen ${ }^{2}$ \\ ${ }^{1}$ MTT Agrifood Research Finland, Plant Production Research, FI-31600 Jokioinen, Finland \\ ${ }^{2}$ MTT Agrifood Research Finland, Services Unit, FI-31600 Jokioinen, Finland \\ email: firstname.lastname@mtt.fi
}

\begin{abstract}
Climate change offers new opportunities for Finnish field crop production, which is currently limited by the short growing season. A warmer climate will extend the thermal growing season and the physiologically effective part of it. Winters will also become milder, enabling introduction of winter-sown crops to a greater extent than is possible today. With this study we aim to characterise the likely regional differences in capacity to grow different seed producing crops. Prolongation of the Finnish growing season was estimated using a $0.5^{\circ}$ latitude $\times 0.5^{\circ}$ longitude gridded dataset from the Finnish Meteorological Institute. The dataset comprised an average estimate from 19 global climate models of the response of Finnish climate to low (B1) and high (A2) scenarios of greenhouse gas and aerosol emissions for 30-year periods centred on 2025, 2055 and 2085 (Intergovernmental Panel on Climate Change). Growing season temperature sums that suit crop growth and are agronomically feasible in Finland are anticipated to increase by some $140{ }^{\circ} \mathrm{Cd}$ by $2025,300^{\circ} \mathrm{Cd}$ by 2055 and $470{ }^{\circ} \mathrm{Cd}$ by 2085 in scenario $\mathrm{A} 2$, when averaged over regions, and earlier sowing is expected to take place, but not later harvests. Accordingly, the extent of cultivable areas for the commonly grown major and minor crops will increase considerably. Due to the higher base temperature requirement for maize (Zea mays L.) growth than for temperate crops, we estimate that silage maize could become a Finnish field crop for the most favourable growing regions only at the end of this century. Winters are getting milder, but it will take almost the whole century until winters such as those that are typical for southern Sweden and Denmark are experienced on a wide scale in Finland. It is possible that introduction of winter-sown crops (cereals and rapeseed) will represent major risks due to fluctuating winter conditions, and this could delay their adaptation for many decades. Such risks need to be studied in more detail to estimate timing of introduction. Prolonged physiologically effective growing seasons would increase yielding capacities of major field crops. Of the current minor crops, oilseed rape (Brassica napus L.), winter wheat (Triticum aestivum L.), triticale (X Triticosecale Wittmack), pea (Pisum sativum L.) and faba bean (Vicia $f a b a \mathrm{~L}$.) are particularly strong candidates to become major crops. Moreover, they have good potential for industrial processing and are currently being bred. Realisation of increased yield potential requires adaptation to 1) elevated daily mean temperatures that interfere with development rate of seed crops under long days, 2) relative reductions in water availability at critical phases of yield determination, 3) greater pest and disease pressure, 4) other uncertainties caused by weather extremes and 5) generally greater need for inputs such as nitrogen fertilisers for non-nitrogen fixing crops.
\end{abstract}

Key-words: Climate change, cultivation area, yield, potential, barley, oat, wheat, rye, triticale, rapeseed, pea, maize, seed crops, minor crops 


\section{Peltonen-Sainio et al. Climate change and Finnish field crop production}

\section{Introduction}

On a global scale, the potential for food production is projected to increase, when local average temperatures increase only slightly $\left(1-3{ }^{\circ} \mathrm{C}\right)$. However, with higher increases in average temperatures, the global potential for food production will decrease (Intergovernmental Panel on Climate Change, IPCC 2007a). Average global surface temperatures have already increased by $0.76^{\circ} \mathrm{C}$ during the last century, with increase in the pace of warming during the last couple of decades (IPCC 2007b). Changes in climate have also occurred at high latitudes (Klein Tank et al. 2002, Klein Tank and Können 2003, Jylhä et al. 2004) and in the future temperatures are generally expected to rise even more in the high latitude countries than elsewhere (IPCC 2007b). In northernmost Europe, especially in Finland, crop production occurs at higher latitudes than anywhere else. In Sweden some $90 \%$ of field crop production occurs in more southerly regions than in Finland (Peltonen-Sainio et al. 2009a). According to Carter (1998) and Klein Tank et al. (2002), the growing season has already become several days longer in Finland, which has already resulted in farmers sowing spring cereals, sugar beet (Beta vulgaris L. var. altissima) and potato (Solanum tuberosum L.) earlier (Kaukoranta and Hakala 2008). This is an example of a spontaneous adaptation measure in Finland. However, spontaneous adaptation has its evident limitations and more co-ordinated, regionally tailored strategies need to be developed to cope with accelerated rates of climate change in the future (Olesen et al. 2009). Furthermore, expected changes in climate are likely to be well outside the experience of farmers and agricultural advisers and hence, entail radical changes in crop production practices and systems. By this means field crop production would be able to meet challenges and take opportunities brought about by changing climate, especially if weather extremes become more frequent (Klein Tank and Können 2003, Alexander et al. 2006, IPCC 2007b).

Even though climate change is likely to present challenges for agricultural and horticultural production in the northern regions, yield potential per se may increase markedly, especially due to extension of the thermal and physiologically effective growing seasons (Peltonen-Sainio et al. 2009b and $2009 \mathrm{c}$ ). In the past hundred years the growing season has been extended, especially at the start, to enable earlier sowing (Carter 1998). Even with more growth-favouring temperatures in the future, lengthening of the growing season in the autumn is not likely to support growth as efficiently as lengthening in the spring, because of low light intensity and short days (GAISMA 2009). Moreover, increasing autumn precipitation and its effects on harvesting conditions, yield losses and yield quality (Jylhä et al. 2004, IPCC 2007b, Peltonen-Sainio et al. 2009d) would likely restrict any temperaturederived benefits of extending the harvesting time in grain and seed crops. Therefore, risks related to prolonging the end of the growing season are likely much higher compared to benefits. Furthermore, anticipated increases in autumn precipitation (Jylhä et al. 2004, IPCC 2007b) and changes in overwintering conditions (Jylhä et al. 2008) may hamper sowing winter crops at present sowing window and affect winter survival until cold winters are replaced by mild winters currently typical of north-western and southern Europe.

As the length of the growing season is the predominant factor limiting crop and cultivar selection and productivity in northern European regions, an increase in duration of the most critical growth phases and introduction of winter sown cultivars will markedly enhance the yield potential of many crops (Carter et al. 1996, Carter 1998, Olesen and Bindi 2002, Peltonen-Sainio et al. 2009c). It is possible that in the future the Nordic countries play an increasingly important role in agricultural production in Europe (Olesen and Bindi 2002). However, because of more frequent weather extremes in the future (Klein Tank and Können 2003, Alexander et al. 2006, IPCC 2007b), but also due to higher incidences of pests and diseases (Carter et al. 1996), production uncertainty increases. Therefore, farmers may rely on the most stable crop species only, which would mean that agrobiodiversity is challenged by climate change.

Climate change impacts on crop productivity and risks differ according to crop species and cul- 
Vol. 18 (2009): 171-190.

tivars. Some crops will benefit from the warming climate more than others, while other crops and cultivars may face major problems and will fall out of production. For example, only slightly elevated temperatures were shown to challenge yield potential of spring sown seed crops, but not winter sown ones (Peltonen-Sainio et al. 2009d), while grass crops appeared to benefit from elevated temperatures (Hakala and Mela 1996). Root crops such as sugar beet and potato will be favoured by longer growing seasons and elevated $\mathrm{CO}_{2}$ levels (Olesen and Bindi 2002). However, the conditions will also favour pathogens, which may cause major yield losses (Carter et al. 1996, Kaukoranta 1996, Hannukkala et al. 2007). Thus, it is likely that adaptation requirements, both regarding breeding and development of cropping systems, are going to vary greatly from one crop type and species to another. This creates an evident need for tailored adaptation strategies. With this study we aim to characterise the likely regional differences in capacity to grow different crops, concentrating on seed producing crops. This is based on climate change induced prolongation of the physiologically effective part of the thermal growing season. This allows assessment of the possible range of increase in crop productivity resulting from extended growing time and potential improvements gained through plant breeding.

\section{Material and methods}

\section{Climate datasets and estimations of prolongation of growing season}

Global climate model projections described by the IPCC have been analysed to extract information on recent and future climate over the Finnish regions. The projections comprised simulations for the period 2010 to 2100 from 19 global models assuming two different scenarios of future greenhouse gas and aerosols emissions to the atmosphere described by the B1 (low emissions) and A2 (high emissions) scenarios of the IPCC (Nakicenovic et al. 2000). Long term mean daily temperatures for the baseline period (1971-2000) were derived from monthly means produced by the Finnish Meteorological Institute (Venäläinen et al. 2005). To obtain monthly means for the three future 30 year periods centred on 2025, 2055 and 2085, an average was taken of the temperature changes (future 30 year span minus the baseline period mean) simulated in 19 global climate models by Finnish Meteorological Institute (Peltonen-Sainio et al. 2009b). For all periods, a grid spacing of $0.5^{\circ}$ latitude $\times 0.5^{\circ}$ longitude was used: all subsequent estimations and calculations were based on the same grid. Daily mean temperatures for each calendar day were derived at every grid point using a six-component Fourier expansion fitted to the annual course of monthly mean temperature (Peltonen-Sainio et al. 2009b).

The beginning of the physiologically effective growing season, a potential sowing day for a recent period (1971-2000), was approximated from regional sowing dates collected by TIKE (the Information Centre of the Ministry of Agriculture and Forestry in Finland). The average sowing day fell between $15^{\text {th }}$ and $21^{\text {st }}$ May in spring cereals, depending on region. This regional information was applied to other crops as well, because no explicit, long-term information was available for them, and in general, sowing window in Finland is very limited (Peltonen-Sainio et al. 2009a). Also according to MTT Official Variety Trials the differences in sowing times among major field crops studied here were not high enough to cause any major error to our estimated regional sowing times. Appropriate sowing days for 30-year periods centred on 2025, 2055 and 2085 (hereon referred to as 2025,2055 and 2085 , respectively) were defined with reference to temperature conditions at sowings in 1971-2000, with projected temperatures indicating that respective sowing dates would occur approximately one, two and three weeks earlier, respectively, than in 19712000. We also noticed that in case of having further earlier sowing by e.g. one week in each period would have resulted in only negligible increase in accumulated temperature sum. This confirmed 


\section{AGRICULTURAL AND FOOD SCIENCE}

\section{Peltonen-Sainio et al. Climate change and Finnish field crop production}

that our estimated sowing dates did not underestimate the possibilities for earlier sowing windows. Previously Carter and Saarikko (1996) and Saarikko and Carter (1996) estimated the likely future sowing time for spring wheat (Triticum aestivum L.) in Finland. They also used technique of having mean temperature (exceeding $8{ }^{\circ} \mathrm{C}$ ) as an indicator of sowing date, but instead of regional data from TIKE, they used information on sowing time of spring wheat and local temperatures of MTT Official Variety Trials only (Carter and Saarikko 1996). In a comparison of the two sowing data sources, Saarikko and Carter (1996), found that the sowing dates estimated by MTT variety trial data differed only by 0.4 days from the actual regional TIKE sowing data. In our study, the daily mean air temperature at sowing times now (1971-2000) and with one, two and three weeks earlier sowings in 2025, 2055 and 2085, respectively, was $8.5-9.5^{\circ} \mathrm{C}$, which corresponds well with the studies of Carter and Saarikko (1996).

The datasets of TIKE and MTT showed the $15^{\text {th }}$ September to be the likely latest appropriate harvesting day, the end of the physiologically effective growing season, in the entire country. We also tested the effects of having one week earlier or delayed harvest in future periods compared with the current $15^{\text {th }}$ September, which is considered to be critical for success (PeltonenSainio et al. 2009b, 2009c). By this means the effect of possible changes in time of harvest on accumulated temperature sum was estimated. Effect of difference by one week in timing of harvest was in general marginal for our approach of estimating the likely northern border for each crop species in future periods. Hence, we only show here the results with harvests at $15^{\text {th }}$ September. On the other hand, delaying harvest more than by one week might drastically increase the risks compared to yield benefits (Peltonen-Sainio et al. 2009a, 2009b).

Cumulative temperature sums for the physiologically effective growing season at base temperatures of +5 and $+10{ }^{\circ} \mathrm{C}$ were calculated for $\mathrm{B} 1$ and A2 scenarios of the IPCC. MapInfo Vertical Mapper was the software used to interpolate values between gridpoints using the Natural Neigh- bour interpolating method. The result from this interpolating was a new grid-file with $0.033^{\circ}$ cell size. This new grid-file was used to make coloured raster maps and contours for temperature sums and they were combined by MapInfo Professional software.

We gathered information from the literature to weight the general potential of different crop species to future conditions in Finland according to each crop's current regional importance and basic growth requirements (Table 1). Furthermore, for maize we used an additional approach with $+10{ }^{\circ} \mathrm{C}$ as a base temperature (Martin et al. 2006, Fronzek and Carter 2007) instead of $+5^{\circ} \mathrm{C}\left( \pm 1^{\circ} \mathrm{C}\right)$ that is typically used for temperate crops (e.g. Kontturi 1979, Kleemola 1991). The information on general thermal requirement of crop maturation in ${ }^{\circ} \mathrm{Cd}$ (Kontturi 1979, Martin et al. 2006, Fronzek and Carter 2007, Peltonen-Sainio et al. 2009c) was compared with projected, regional changes in accumulated ${ }^{\circ} \mathrm{Cd}$ and duration of the physiologically effective (but also agronomically feasible) growing season for grain and seed crops.

\section{Estimations for winters}

Thermal winter is determined to be the period starting, when daily mean temperatures remain permanently below $0{ }^{\circ} \mathrm{C}$ and ending when they rise permanently above $0{ }^{\circ} \mathrm{C}$. We estimated the climate change effects on length of thermal winter in B1 and A2 scenarios of the IPCC by recording regional borderlines for winters with 75, 50 and 25 frost days in 2025, 2055 and 2085, respectively. 25 frost days is close to the length of the thermal winter at present (1961-1990) in Denmark (Tveito et al. 2001) and can already be considered a mild winter compared with the current Finnish cold winters. Outcome of estimation of thermal winters according to 30-year means may differ somewhat from computation of each year first before averaging over each 30-year period. MapInfo Vertical Mapper and MapInfo Professional were the software used as described above. 
Vol. 18 (2009): 171-190.

Table 1. Novel or current minor field crops in Finland grown elsewhere in Europe and considered in this study. Source: Smartt and Simmonds (1995), Rousi (1997) and FAO (2009).

\begin{tabular}{|c|c|c|}
\hline Field crop & Included & Reasoning \\
\hline \multicolumn{3}{|l|}{ Annuals: } \\
\hline Cotton (Gossypium sp.) & no & Potential for temperate latitudes; in Europe grown only up to $47^{\circ} \mathrm{N}$. \\
\hline Faba bean (Vicia faba L.) & yes & $\begin{array}{l}\text { Potential, temperate crop, small-scale growing and breeding in } \\
\text { Finland. }\end{array}$ \\
\hline Flax (Linum usitatissimum L.) & yes & $\begin{array}{l}\text { Potential, temperate crop, small-scale growing and breeding in } \\
\text { Finland. }\end{array}$ \\
\hline Hemp (Cannabis sativa L.) & yes & $\begin{array}{l}\text { Potential, temperate crop. Commercial production of oil hemp }{ }^{\text {a) }} \text { and } \\
\text { experimental growing of fibre hemp in Finland }{ }^{\text {b) }} \text {. }\end{array}$ \\
\hline Maize (Zea mays L.) & yes & $\begin{array}{l}\mathrm{C}_{4} \text {-crop favouring high temperatures, some experimental growing in } \\
\text { Finland. Forage (silage) maize has more future potential in northern } \\
\text { European growing conditions than grain maize. }\end{array}$ \\
\hline Mustards (Sinapis spp.) & no & $\begin{array}{l}\text { Potential, temperate crop, small-scale growing in Finland. Co- } \\
\text { existence with other Brassica crops too challenging to enable large- } \\
\text { scale cultivation. }\end{array}$ \\
\hline Pseudocereals & no/yes & $\begin{array}{l}\text { Often sub-tropical and tropical species with minor and/or very re- } \\
\text { gional importance in Europe. Buckwheat (Fagopyrum esculentum } \\
\text { Mill.) most potential and hence, considered further }{ }^{\text {c) }} \text {. }\end{array}$ \\
\hline Soya bean (Glycine $\max \mathrm{L}$. ) & no & $\begin{array}{l}\text { Oil and protein crop favouring high temperatures. Presently adapt- } \\
\text { ed to the southernmost Europe and e.g., Russia, Czech Republic and } \\
\text { Ukraine, but not Scandinavia or Baltic countries. Unlikely to have } \\
\text { breakthrough in the northernmost regions of Europe within this cen- } \\
\text { tury according A } 2 \text { scenario. }\end{array}$ \\
\hline Sunflower (Helianthus annuus L.) & yes & $\begin{array}{l}\text { Potential, temperate crop, small-scale growing in Finland, large- } \\
\text { scale growing e.g. in Russia. }\end{array}$ \\
\hline \multicolumn{3}{|l|}{ Winter types or perennials: } \\
\hline Hops (Humulus lupulus L.) & no & $\begin{array}{l}\text { Potential, temperate crop with overwintering rootstock. Main pro- } \\
\text { duction areas in Central Europe. }\end{array}$ \\
\hline Lupins (Lupinus spp.) & yes & $\begin{array}{l}\text { Potential, temperate crops, especially L. angustifolius. Grown main- } \\
\text { ly in Central and Eastern Europe (e.g., Germany, Poland, Belarus, } \\
\text { Russia) and France, small scale growing in Lithuania, experimental } \\
\text { growing in Finland }^{\text {d) }} \text {. }\end{array}$ \\
\hline Triticale (X Triticosecale Wittmack) & yes & $\begin{array}{l}\text { Potential, temperate crop, small-scale growing in Finland. Grown in } \\
\text { Europe up to Denmark. }\end{array}$ \\
\hline Winter barley (Hordeum vulgare L.) & yes & $\begin{array}{l}\text { Potential, temperate crop. Grown in Northern and Central Europe, } \\
\text { significantly up to Denmark. }\end{array}$ \\
\hline Winter oat (Avena sativa L.) & yes & Potential, temperate crop. Grown in Europe significantly in UK. \\
\hline Winter oilseed rape (Brassica napus L.) & yes & $\begin{array}{l}\text { Potential, temperate crop. Largely grown in Europe, but not in } \\
\text { Finland. }\end{array}$ \\
\hline Winter turnip rape (B. rapa L.) & yes & $\begin{array}{l}\text { Potential, temperate crop. Grown in Northern Europe; in Finland in } \\
\text { the } 1950 \mathrm{~s} \text { to } 1960 \mathrm{~s}^{\mathrm{e})} \text {. }\end{array}$ \\
\hline
\end{tabular}

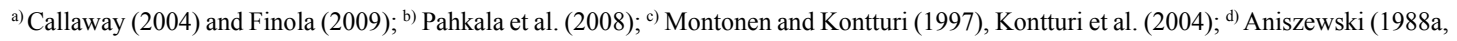
1988b), Kurlovich et al. (2004); ${ }^{\text {e) }}$ Hiivola (1966) 


\section{Peltonen-Sainio et al. Climate change and Finnish field crop production}

\section{Estimations of changes in yielding capacity}

Two factors were taken into account when changes in yielding capacity were modelled: longer and warmer physiologically effective growing season and genetic yield improvement. According to Öfversten et al. (2004) and Peltonen-Sainio et al. (2009d), annual genetic improvement is $0.64,0.41$, $1.01,0.85$ and $1.53 \%$ for barley (Hordeum vulgare L.), oat (Avena sativa L.), spring wheat, turnip rape (Brassica rapa L.) and oilseed rape (Brassica napus L.), respectively. Data from MTT long-term field experiments conducted in 1970-2008 and the model suggested by Öfversten et al. (2004) were used to calculate genetic improvement for winter wheat $(0.64 \%)$, winter rye (Secale cereale L.) $(0.97 \%)$ and pea (Pisum sativum L.) (0.40\%). The effect of $\mathrm{CO}_{2}$ increase on yields was ignored and resource limitation (water, nutrients) expected to be comparable to that in the recent period.

The increased yield potential from a prolonged growing season was analysed using two methods, one simple and one more complex. In the simple approach all results of MTT long-term field experiments conducted in 1990-2008 were classified according to cumulative temperature sum between sowing and yellow ripening. The classes were 700800, 800-900, 900-1000, 1000-1100, 1100-1200 and $1200-1300{ }^{\circ} \mathrm{Cd}$. The means of all yields in each class were calculated and thereby, the general association with yield and increase in temperature sum determined. The more complex approach was based on a two-stage computation. The two-stage computation was needed, because mutually comparable yield levels and growing times were needed as a starting point when the relationship between these was estimated. The modern cultivars in the MTT long-term field experiments (years 20012008) and the following statistical model were used in the first stage:

$\mathrm{y}_{\mathrm{ijkl}}=\mu+$ cultivar $_{\mathrm{i}}+$ year $_{\mathrm{j}}+$ site $_{\mathrm{k}}+$ experiment $_{\mathrm{jkl}}+\varepsilon_{\mathrm{ijkl}}$,

where $y_{i j k l}$ is the observation, $\mu$ is the intercept, and cultivar ${ }_{i}$ is the fixed effect of the $i^{\text {th }}$ cultivar. Year $_{\mathrm{j}}$, site $_{\mathrm{k}}$, experiment ${ }_{\mathrm{jkl}}$ and $\varepsilon_{\mathrm{ijkl}}$ represent random effects of the $\mathrm{j}^{\text {th }}$ year, the $\mathrm{k}^{\text {th }}$ site, the $\mathrm{l}^{\text {th }}$ experiment and the residual. For example, yield of oat cultivar Veli was $6236 \mathrm{~kg} \mathrm{ha}^{-1}$ in a trial in Pälkäne (61 ${ }^{\circ} 20^{\text {' }}$ $\mathrm{N}, 24^{\circ} 16^{\prime} \mathrm{E}$ ) in 2001 . According to the model, the estimated average yield of this cultivar was 5103 $\mathrm{kg} \mathrm{ha}^{-1}$, environmental effects of Pälkäne in 2001 were $1165 \mathrm{~kg} \mathrm{ha}^{-1}$ in total, and unexplained variation, residual, was $-32 \mathrm{~kg} \mathrm{ha}^{-1}$. Estimated average effective temperature sum before maturity for Veli was $910^{\circ} \mathrm{Cd}$ using the same statistical model. The model was fitted using the SAS/MIXED procedure and the REML estimation method. Estimates of cultivar $_{i}$ were used to calculate average level of yield in the period of 2001-2008.

In the second stage, the following regression model was fitted using the SAS/REG procedure:

$$
\text { yield }_{i}=\alpha+\beta \text { time }_{i}+\varepsilon_{i},
$$

where yield $_{i}$ and time ${ }_{i}$ are previously estimated yield and growing time for the $\mathrm{i}^{\text {th }}$ cultivar (see Eq. 1, e.g. $5103 \mathrm{~kg} \mathrm{ha}^{-1}$ and $910^{\circ} \mathrm{Cd}$ for maturation for cultivar Veli), $\alpha$ is the intercept, $\beta$ is the regression coefficient for growing time and $\varepsilon_{\mathrm{i}}$ is the residual. Increased yield potential for a prolonged and warmer growing season of one ${ }^{\circ} \mathrm{Cd}$ was set to be $\hat{\beta}$, i.e. cultivars with long growing time contributed to increased yield potential and regression coefficient expressed the amount of increased potential. This coefficient was used to predict a potential yield for the future periods with the prolonged and warmer growing seasons.

Potential yield for all grid points and for periods 1985, 2025, 2055 and 2085 was calculated using the following equation:

yield $_{\mathrm{m}}=(\chi+\hat{\beta} * v)^{*}(1+\lambda)^{(\mathrm{m}-2005)}$,

where $\mathrm{m}$ is the period $(\mathrm{m}=1985,2025,2055$ or 2085), $\chi$ is the average level of yield in period of 2001-2008 (see Eq. 1), $\hat{\beta}$ is increased yield potential of prolonged and warmer growing season (see Eq. 2), $v$ is change in temperature sum and $\lambda$ is annual genetic improvement (Öfversten et al. 2004). Change, $v$, was calculated for B1 and A2 scenarios of the IPCC (see "estimations of prolongation of growing season"). For example, $\lambda$ could be $0.41, \chi 5328 \mathrm{~kg}$ $\mathrm{ha}^{-1}$ and $\hat{\beta} 7.47 \mathrm{~kg} \mathrm{ha}^{-1}{ }^{\circ} \mathrm{Cd}^{-1}$ for oats. $v$ is defined as 
Vol. 18 (2009): 171-190.

$64^{\circ} \mathrm{Cd}$ in one grid point where accumulated effective temperature sums for oats were $1200^{\circ} \mathrm{Cd}$ and $1264^{\circ} \mathrm{Cd}$ in periods 2005 and 2025 , respectively. After this the potential yield level was $6301 \mathrm{~kg} \mathrm{ha}^{-1}$ in period 2025. The accumulated temperature sum was $1104^{\circ} \mathrm{Cd}$ and corresponding yield level 4249 $\mathrm{kg} \mathrm{ha}^{-1}$ in period 1985. To make presentation of the results easier, the mean of potential yields at the same latitude was calculated.

Furthermore, in order to consider the major challenges related to achieving such climate change enhanced yield potentials of field crops for Finnish growing conditions, we listed the principal adaptation measures according to the literature.

Regarding crops not presently grown on a large scale in Finland, we gathered information from the literature to estimate the actual yields at lower latitudes with a growing season similar in length to that for our future projections.

\section{Results and discussion}

\section{Prolonged growing seasons and potential growing regions for spring sown crops}

Finland is the world's most northern field crop production region (Peltonen-Sainio et al. 2009a) and anthropogenically-induced climate warming is expected to be especially high at such northern latitudes (IPCC 2007b). Climate warming will change length and cause changes in conditions both during the growing season and during the overwintering period. Considering the changes to the physiologically effective part of a prolonged thermal growing season that can support crop growth and development, we noted that the typical length of the growing season in Central Finland by the 2025 under both B1 and A2 scenarios is projected to resemble that currently found in southern Finland $\left(1100-1200^{\circ} \mathrm{Cd}\right)$. Southern Finland already experiences growing seasons with $1300^{\circ} \mathrm{Cd}$ (Fig. 1). However, by $20551100-1200^{\circ} \mathrm{Cd}$ growing seasons are projected for Oulu region $\left(65^{\circ} \mathrm{N}, 25^{\circ} \mathrm{E}\right)$ in the $\mathrm{B} 1$ scenario and $1300^{\circ} \mathrm{Cd}$ in the $\mathrm{A} 2$ scenario. By mid-century $1400-1500^{\circ} \mathrm{Cd}$ growing seasons would be typical for southern Finland, depending on the climate change scenario. Uncertainties in climate warming projections increase towards the end of this century. However, they indicate 1700 ${ }^{\circ} \mathrm{Cd}$ (A2 scenario) and $1500{ }^{\circ} \mathrm{Cd}$ (B1 scenario) for southern Finland by the end of century. According to these projections changes would proceed rapidly at latitudes $\geq 60^{\circ} \mathrm{N}$, even though we estimated only moderate changes in sowing times and none for harvests. If these estimations transpire there are new prospects for Finnish agriculture.

We considered the future regional potential for production of different crops only according to the projected lengthening of the physiologically effective growing season and effective temperature sum (growing degree days), and excluded issues such as existence of fields in different regions, field sizes and distances, need for basic field repairs and other investments, soil types, distribution of precipitation and role of grasslands. Employing this approach, we established potential for considerable expansion in production of many spring sown crops, comparing the lengths of the growing seasons $\left(\right.$ in ${ }^{\circ} \mathrm{Cd}$ ) in the future with the basic, recorded requirements of crops when grown under long day conditions at high latitudes (Table 2). Crops that require $1000-1100{ }^{\circ} \mathrm{Cd}$ and/ or are prone to frost [buckwheat (Fagopyrum esculentum Mill.), faba bean (Vicia faba L.), flax (Linum usitatissimum L.), oil hemp (Cannabis sativa L.), oilseed rape, turnip rape and sunflower (Helianthus annuus L.)] are currently grown at up to $62^{\circ} \mathrm{N}$ or only in the most temperature favoured regions of southern Finland. Within the next couple of decades they might be grown at up to $65^{\circ} \mathrm{N}$ along with crops like field pea and spring cereals that would not be limited by length of the growing season in regions where there is arable land (Fig. 1, Table 2). Such anticipated changes in production regions of crops like turnip rape and oilseed rape (see Peltonen-Sainio et al. 2009b for more detailed discussion), as well as pea and faba bean, represent promising prospects for expanding production of protein rich crops in northern 


\section{AGRICULTURAL AND FOOD SCIENCE}

\section{Peltonen-Sainio et al. Climate change and Finnish field crop production}
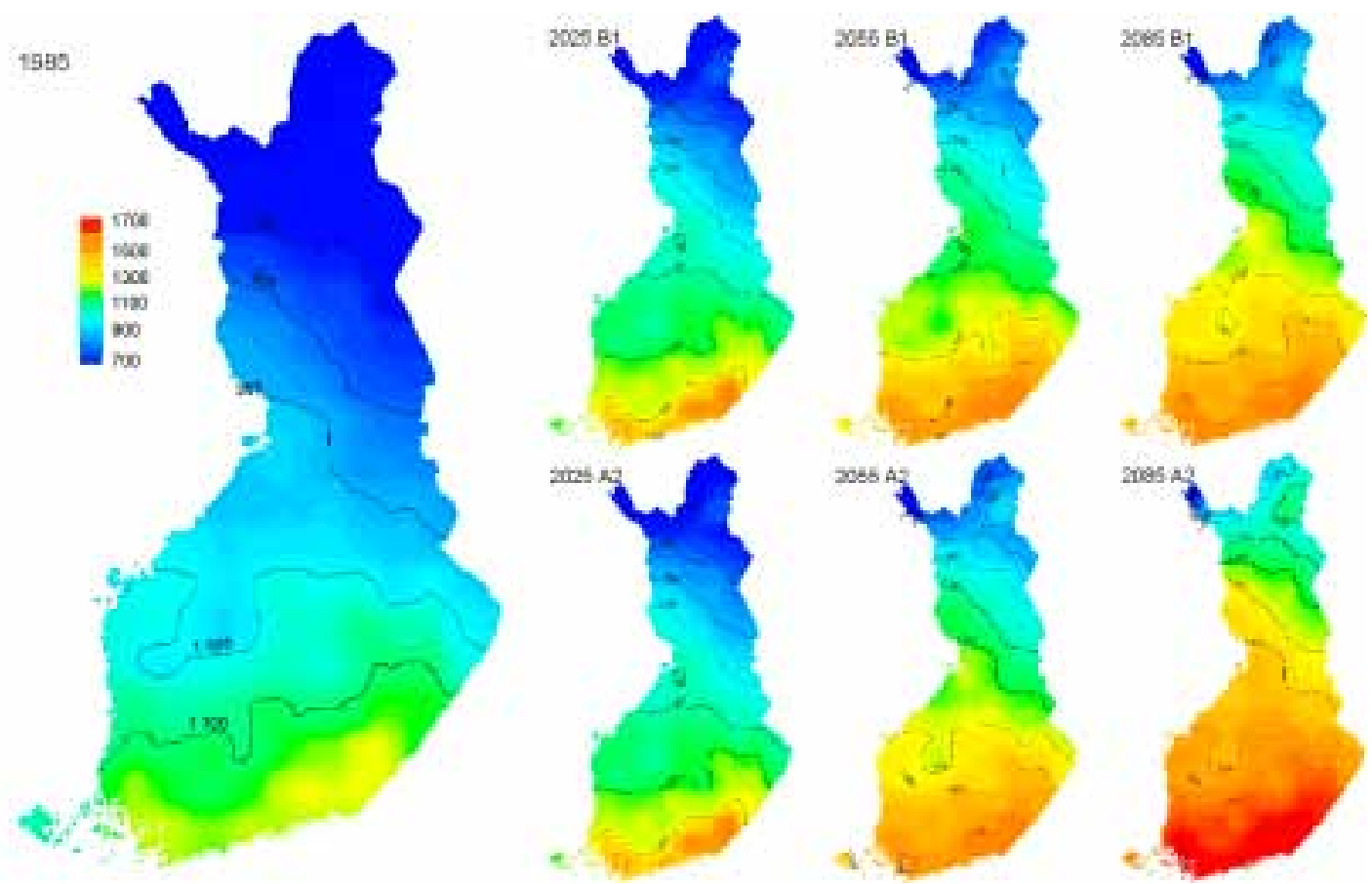

Fig. 1. Physiologically effective and agronomically feasible growing season accumulated temperature sum $\left({ }^{\circ} \mathrm{Cd}\right)$ from estimated sowing to harvest with $+5^{\circ} \mathrm{C}$ base temperature during recent decades (1971-2000) centered on 1985 and estimations for 30-year periods centred on 2025, 2055 and 2085 according to B1 and A2 scenarios of the IPCC and 19 climatic models (data from the Finnish Meteorological Institute). Regional means for sowing dates (1971-2008) are from TIKE (the Information Centre of the Ministry of Agriculture and Forestry in Finland); for the future the appropriate sowing times are identified to be approximately one, two and three weeks earlier for 2025, 2055 and 2085, respectively. Harvests are expected to occur by $15^{\text {th }}$ September due to potentially unfavourable growing and harvest conditions.

regions that are not currently self-sufficient at all in protein crop production (Aronen 2008).

In most cases of temperate crops evaluated +5 ${ }^{\circ} \mathrm{C}$ was the base temperature for cumulated degrees, but maize is $\mathrm{C}_{4}$-crop favouring higher daily mean temperatures and we therefore used $+10^{\circ} \mathrm{C}$ as the base temperature (Martin et al. 2006) (Fig. 2 ). Even in the A2 scenario, elevation of temperatures seemed not to be sufficient to secure production of grain maize in Finland. Grain maize has in fact only recently been introduced into Denmark due to elevated temperatures during the growing season, while forage maize has been an important crop there for a long time (Olesen et al. 2009). Ac- cording to expected warming in Finland (Fig. 2), forage maize could be introduced into southern Finland, without likely major risks resulting from too short a growing season, night frosts and cool periods, by the mid-century according to the A2 scenario, but only by the end of the century in the B1 scenario. In a controlled condition experiment at MTT, Jokioinen, in 2008, where temperature and length of the growing season roughly resembled those expected by the end of the century in the A2 scenario for large areas of southern Finland, forage maize produced ca. $35000 \mathrm{~kg}$ dry matter per hectare (Ari Rajala, MTT, personal communication $13^{\text {th }}$ February 2009). 
Vol. 18 (2009): 171-190.

Table 2. Minimum accumulated temperature sums required over a base temperature for successful growth of various major and minor spring sown crops and considered as a basic prerequisite for cultivation under northern, long day growing conditions and being critical for crop introduction to new regions following climate change.

\begin{tabular}{lccl}
\hline Field crop & $\begin{array}{c}\text { Base } \\
\text { temperature } \\
\left({ }^{\circ} \mathrm{C}\right)\end{array}$ & $\begin{array}{c}\text { Required physiologically } \\
\text { effective temperature sum } \\
\left({ }^{\circ} \mathrm{Cd}\right)\end{array}$ & Reference \\
\hline Buckwheat & $5-10^{\mathrm{a}}$ & 900 & Montonen and Kontturi (1997) \\
Faba bean & 5 & 1060 & MTT Official Variety Trials \\
Flax & 5 & 1040 & MTT Official Variety Trials \\
Hemp & 5 & 1150 & Callaway (2004), Pahkala et al. (2008) \\
Maize for forage & 10 & $700-850$ & Carter et al. (1991) $)^{\mathrm{c}}$ Martin et al. (2006), \\
Pea & 5 & $930-980$ & Fronzek and Carter (2007) \\
Spring barley & 5 & 890 & MTT Official Variety Trials \\
Spring oat & 5 & 960 & Peltonen-Sainio et al. (2009c) \\
Spring oilseed rape & 5 & 1090 & Peltonen-Sainio et al. (2009c) \\
Spring turnip rape & 5 & 1010 & Peltonen-Sainio et al. (2009c) \\
Spring wheat & 5 & 990 & Peltonen-Sainio et al. (2009c) \\
Sunflower & 5 & 1100 & Peltonen-Sainio et al. (2009c) \\
\hline
\end{tabular}

${ }^{\text {a }}$ Temperature exceeding $+10^{\circ} \mathrm{C}$ is required for seedling emergence.

${ }^{\mathrm{b}}$ Temperature sum for oil hemp is $1150{ }^{\circ} \mathrm{Cd}$, while fibre hemp can be harvested earlier.

${ }^{c}$ Used for grain maize and accumulated over the whole year.

\section{From cold to mild winters and consequent estimated introduction of autumn sown crops}

Future growing seasons will be warmer and longer, but winters will be milder and shorter (Jylhä et al. 2008), as shown in Figure 3. The transition from cold to mild winters is indicated as expansion of regions with fewer frost days than 100, 75, 50 and 25 compared with current winters, which have close to 100 frost days in the south and up to almost 200 if the entire current field crop production area is taken into account. According to these projections basing on averages over 30-year periods, by 2025 the south-western archipelago will be the only region having fewer than 100 frost days for both the B1 and A2 scenarios. However, by 2055 the 100 frost day borderline would approach not only the coastal areas but also inland southern Finland, and by 2085 it reaches Oulu in the A2 scenario (Fig. 3). Scenarios differ markedly in how they anticipate progress of mild winters: in the A2 scenario, borderlines of 25 and 50 frost days cross that of 100 frost days for the B1 scenario. Therefore, particularly in the case of the high-emission scenario, Finnish winters would get clearly milder during this century, and by the end of this century, but not much earlier, there would be mild winters similar to those of southern Sweden at present (1961-1990) (Tveito et al. 2001). Winters in the south-westernmost parts of Finland would be similar to those in Denmark.

Although numerous factors affect success of overwintering capacity of field crops (Hömmö and Pulli 1993, Lindén et al. 1999, Hofgaard et al. 2003, Serenius et al. 2005, Velicka et al. 2006), considering mildness of winters only as a reduction in numbers of frost days, we can estimate the potential time-frame for introduction of currently grown autumn sown crops over a larger extent and 


\section{AGRICULTURAL AND FOOD SCIENCE}

\section{Peltonen-Sainio et al. Climate change and Finnish field crop production}
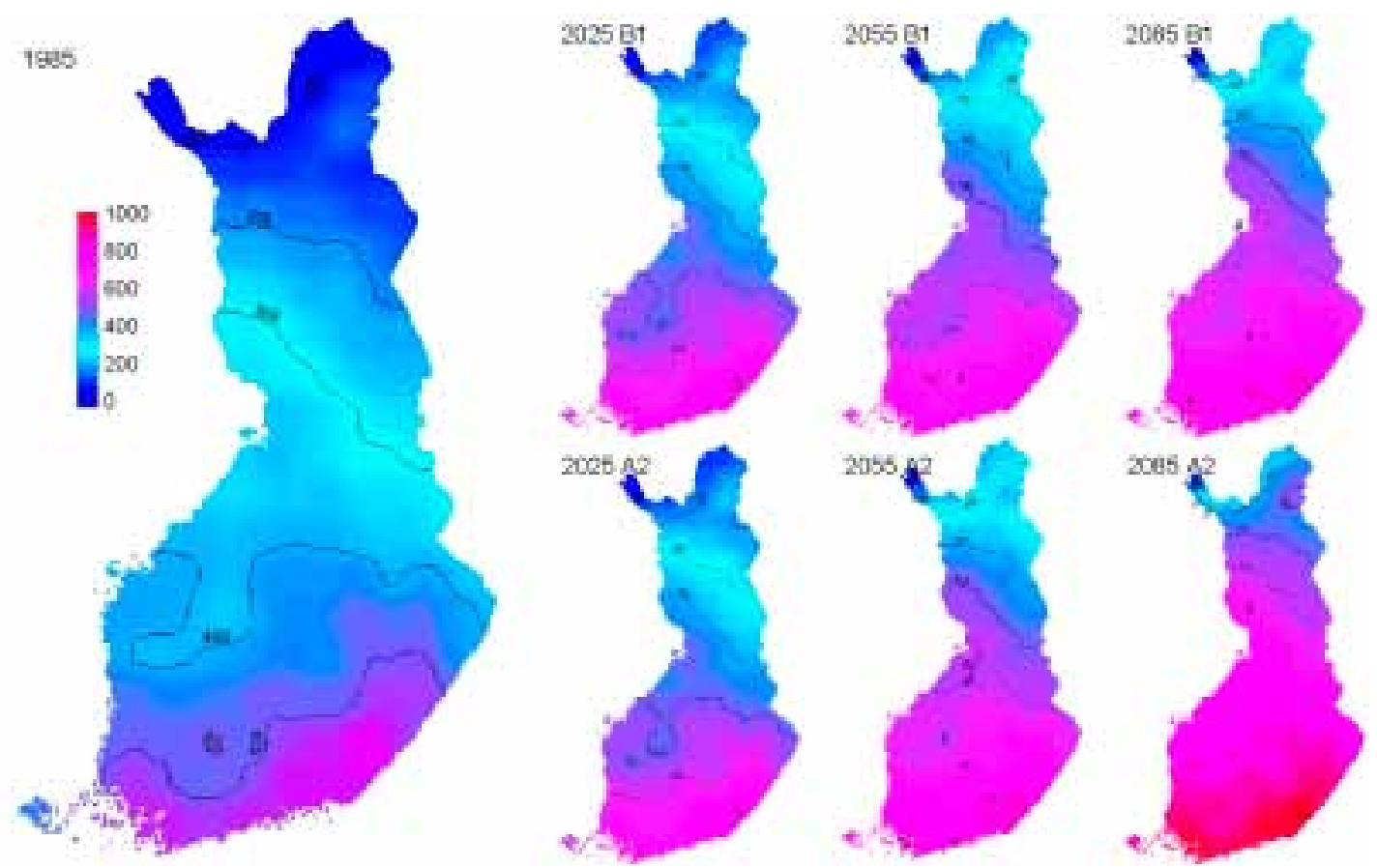

Fig. 2. Physiologically effective and agronomically feasible growing season accumulated temperature sum $\left({ }^{\circ} \mathrm{Cd}\right)$ from estimated sowing to harvest with $+10^{\circ} \mathrm{C}$ base temperature during recent decades (1971-2000) centered on 1985 and estimations for 30-year periods centred on 2025, 2055 and 2085 according to B1 and A2 scenarios of the IPCC and 19 climatic models (data from the Finnish Meteorological Institute). Regional means for sowing dates (1971-2000) are from TIKE (the Information Centre of the Ministry of Agriculture and Forestry in Finland); for the future the appropriate sowing times are identified to be approximately one, two and three weeks earlier for 2025, 2055 and 2085, respectively. Harvests are expected to occur by $15^{\text {th }}$ September due to potentially unfavourable growing and harvest conditions.

introduction of novel overwintering crop species. For example, cultivation of winter wheat, currently grown only in restricted areas of southern Finland where there are about 130 frost days at most, can be extended to the Oulu region by end of this century in the A2 scenario (Fig. 3). Rye production could be successful throughout the arable regions by 2055 in the A2 scenario. Triticale (X Triticosecale Wittmack) has occasional overwintering success under current winter conditions and could become a major field crop in Finland. Its cultivation could probably extend a little beyond the expansion of winter wheat in the future.

In contrast to winter rye, wheat and triticale, we lack experience in cultivation of winter cultivars of barley, oat, turnip rape and oilseed rape. Winter turnip rape areas in the 1950 s tended to- wards 10000 hectares (Hiivola 1966), but cultivar development has been considerable since then. Without comprehensive data from experiments in Finland we have to rely on information from more southern regions, especially Sweden, Denmark and Estonia, and compare their current with our future conditions.

Currently winter oilseed rape is largely grown in Sweden, particularly the southern parts, (Svensk Raps 2009), and in Denmark, but not in Estonia because of poor overwintering capacity (Lääniste et al. 2008). Comparison of our future winter conditions with those of the current Brassica production regions of Sweden and Denmark (Tveito et al. 2001, period 1961-1990) indicates that autumn sown Brassica crops could enter into cultivation in the current spring sown Brassica crop 


\section{AGRICULTURAL AND FOOD SCIENCE}

Vol. 18 (2009): 171-190.

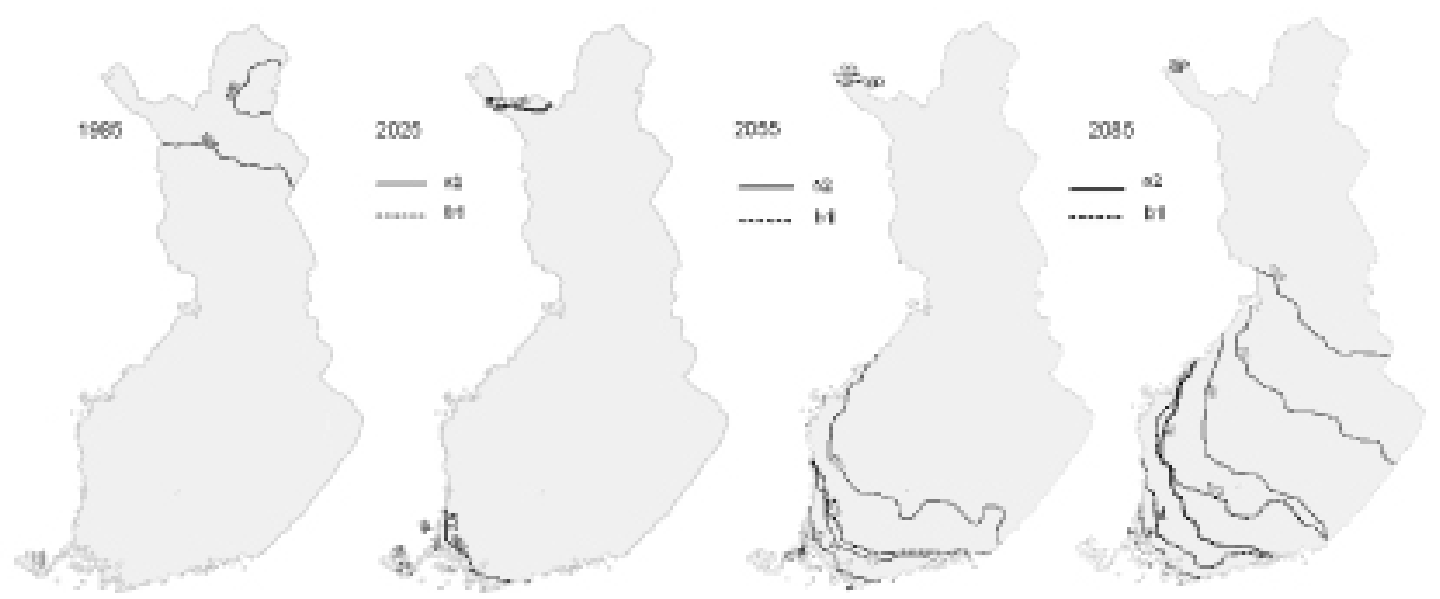

Fig. 3. Estimated changes in thermal winter determined as a period (in days) starting when daily mean temperatures remain permanently below $0{ }^{\circ} \mathrm{C}$ and ending when they rise permanently above $0{ }^{\circ} \mathrm{C}$. The regional time points for winters with 75, 50 and 25 frost days, from which 25 days is close to the current length of thermal winter in Denmark, are shown for recent decades (1971-2000) centered on 1985 and estimations for 30-year periods centred on 2025, 2055 and 2085 according to B1 and A2 scenarios of the IPCC and 19 climatic models (data from the Finnish Meteorological Institute).

region of Finland by mid-century at the earliest, or more probably by the end of this century (Fig. 3 ). However, early spring frosts are particularly critical for successful overwintering of Brassica crops, not just the winter conditions and length of the thermal winter per se (Johan Biärsjö, Svensk Raps AB, personal communication $5^{\text {th }}$ February 2009). This is in agreement with earlier findings from Finland (Hiivola 1966), which showed that the main reasons for poor overwintering of winter turnip rape were frost and waterlogging. In the future, with projected increases in winter precipitation and cycles of thawing and freezing (Jylhä et al. 2004, 2008), the risk of waterlogging generally increases. For Brassica the apical meristem is prone to frost damage, unlike in cereals which have a well protected apical meristem close to soil surface (Peltonen-Sainio et al. 2009a). Due to this major structural difference between winter cereals and Brassica crops, winter barley, as largely grown in Denmark, and winter oat, which has gradually started to dominate oat production in U.K. (Anon. 1999, Central Statistics Office Ireland 2009), can be introduced into Finnish agriculture somewhat earlier, but no later than autumn sown Brassica crops.
Even though we have concentrated on the issue of how critical overwintering conditions are regarding future expansion of crops to novel regions in Finland, it is important to stress that estimated increases in autumn precipitation could interfere with sowing of winter crops, which has to be taken into consideration in adaptation strategies.

Of the underutilised crops blue lupin (Lupinus angustifolius L.), also called narrow-leafed lupin, is grown in experiments in southern and northern Finland (Aniszewski 1988a, 1988b, Kurlovich et al. 2004). According to Kurlovich et al. (2004), early forms of blue lupin grow successfully in southern Finland when inoculated with Rhizobium, and even in northern Finland dry-matter yields of 1.23 to $7.38 \mathrm{t} \mathrm{ha}^{-1}$ were recorded when cultivars were compared (Aniszewski 1988b). In Finland, Washington lupin (L. polyphyllus Lindl.) is a garden escapee, which flourishes by the roadsides and indicates the general potential of lupins to adapt successfully to northern conditions (Aniszewski et al. 2001). Lupins are also likely to benefit from climate induced changes in Finnish conditions and could represent a valuable addition to the group of nitrogen fixing protein crops in the future. 


\section{Peltonen-Sainio et al. Climate change and Finnish field crop production}

\section{Estimated changes in yield potential of major field crops currently grown in Finland}

Spring cereals. For our estimations we considered that a combination of climate change and plant breeding would increase yield potential in cereals as for all crops in the future. However, in the future growing regions would differ according to their yield potential, as shown in Table 3 for spring sown cereals. Current barley grain yields in southernmost Finland are likely to be lower than the yield potential anticipated for $64-66^{\circ} \mathrm{N}$ by 2025 regardless of scenario. Furthermore, estimated potential yields of barley for 2055 at $60^{\circ} \mathrm{N}$ would be reached at $66^{\circ} \mathrm{N}$ by the end of this century, while for wheat the pace of improvements is set to be even higher. These striking examples illustrate how strongly the short growing season limits yields under these northernmost European growing conditions. It also reveals the substantial impact of lengthening the growing season in a warming climate on productivity. However, to realise such potential requires adaptation measures, including sufficient input use (especially nitrogen), development of irrigation systems in cases of insufficient water availability at critical phases of crop development, and tailoring crop cultivars to future challenges of changing climate, including too high temperature responsiveness of spring cereals under long day conditions, resistance to pests and diseases and improved nutrient and water use efficiency (Table 4). If we were to exclude any breeding effect and solely consider the effect of prolonged growing season and higher accumulated degree days per se, there would be only negligible yield increases (data not shown). For example, for spring barley the yield difference between seasons

Table 3. Estimated means for enhanced potential yields of spring cereals in 30-year periods centred on 2025, 2055 and 2085 depending on latitude and compared with recent history (1971-2000, centered on 1985). Anticipated potential yields $\left(\mathrm{t} \mathrm{ha}^{-1}\right)$ dependent on ${ }^{\circ} \mathrm{Cd}$ are shown as B1 estimate - A2 estimate. Plant breeding achievements are included in estimations with expectation of pace of genetic yield gain being similar to 1971-2000. Effect of elevated $\mathrm{CO}_{2}$ on yields is ignored. At each latitude potential yields in western regions are slightly higher (ca. 8\%) than in eastern regions. At the end of this century (2085) spring forms are likely to be partly replaced by winter types in the regions with mild winters and their yield potential is estimated only for more northern latitudes. Current record yields from Denmark and Sweden are reached and exceeded at the more southern latitudes by mid-century.

\begin{tabular}{|c|c|c|c|c|c|c|c|c|}
\hline \multirow[t]{2}{*}{ Crop } & \multirow[t]{2}{*}{ Time } & \multicolumn{7}{|c|}{ Latitude } \\
\hline & & $60^{\circ} \mathrm{N}$ & $61{ }^{\circ} \mathrm{N}$ & $62^{\circ} \mathrm{N}$ & $63^{\circ} \mathrm{N}$ & $64^{\circ} \mathrm{N}$ & $65^{\circ} \mathrm{N}$ & $66^{\circ} \mathrm{N}$ \\
\hline \multirow[t]{4}{*}{ Spring barley } & 1985 & 3.5 & 3.5 & 3.3 & 3.1 & 3.0 & 2.8 & 2.3 \\
\hline & 2025 & $5.0-5.0$ & $5.0-5.0$ & $4.8-4.8$ & $4.5-4.5$ & $4.3-4.3$ & $4.1-4.1$ & $3.9-3.9$ \\
\hline & 2055 & $6.4-6.6$ & $6.4-6.7$ & $6.2-6.4$ & $5.9-6.1$ & $5.6-5.9$ & $5.4-5.6$ & $5.1-5.3$ \\
\hline & 2085 & . & . & . & . & $7.2-8.0$ & $6.9-7.7$ & $6.6-7.4$ \\
\hline \multirow[t]{4}{*}{ Spring oat } & 1985 & 4.4 & 4.4 & 4.0 & 3.5 & 3.1 & 2.6 & 1.4 \\
\hline & 2025 & $6.4-6.5$ & $6.5-6.5$ & $5.9-6.0$ & $5.4-5.4$ & $4.8-4.8$ & $4.4-4.4$ & $3.8-3.8$ \\
\hline & 2055 & $8.2-8.8$ & $8.3-8.9$ & $7.7-8.2$ & $7.0-7.5$ & $6.4-6.9$ & $5.9-6.4$ & $5.2-5.7$ \\
\hline & 2085 & . & . & . & . & $8.1-9.8$ & $7.5-9.3$ & $6.7-8.5$ \\
\hline \multirow[t]{4}{*}{ Spring wheat } & 1985 & 2.9 & 2.9 & 2.8 & 2.6 & 2.0 & 1.1 & . \\
\hline & 2025 & $4.9-4.9$ & $4.9-4.9$ & $4.7-4.7$ & $4.4-4.4$ & $4.2-4.2$ & $4.0-4.0$ & $2.7-2.7$ \\
\hline & 2055 & $7.1-7.4$ & $7.1-7.4$ & $6.8-7.1$ & $6.5-6.7$ & $6.1-6.4$ & $5.9-6.1$ & $5.6-5.8$ \\
\hline & 2085 & . & . & $\cdot$ & $\cdot$ & $\cdot$ & $8.4-9.5$ & $7.9-9.1$ \\
\hline
\end{tabular}


Vol. 18 (2009): 171-190.

with 800 and 1100 utilised ${ }^{\circ} \mathrm{Cd}$ was only $350 \mathrm{~kg}$ $\mathrm{ha}^{-1}$, close to $100 \mathrm{~kg} \mathrm{ha}^{-1}$ per $100^{\circ} \mathrm{Cd}$ elevation (data not shown). This was typical for spring and winter cereals, though no comprehensive data were available for exceptionally warm growing seasons with $1300-1500{ }^{\circ} \mathrm{Cd}$. Such direct comparison evidently underestimates the potential changes in yields, as we recently demonstrated both a negative response of today's cultivars to elevated temperatures under long day conditions (Peltonen-Sainio et al. 2007 and 2009d) and lack of sufficient inputs to sustain yields in high productivity years (Peltonen-Sainio et al. 2009e). This was also demonstrated in an earlier study of Saarikko (2000), where modelled yields were considerably higher than those observed at regional level, probably because of insufficient inputs by Finnish farmers. According to earlier experiments and estimations of climate change effects on crop production (Hakala 1998, Saarikko 2000), the increase in growing season temperatures by climate change decreased the yield of wheat (cultivar "Polkka"), and even though yield was increased by elevated $\mathrm{CO}_{2}$, the combined effect of $\mathrm{CO}_{2}$ and temperature resulted in no significant gain but also no significant yield penalty. These results clearly emphasise the role of plant breeding and investment in production inputs for enhancement of yield potential in prolonged and warmer growing

Table 4. The major adaptation measures needed to sustain expression of climate change increased yield potential in future field crop production.

\begin{tabular}{|c|c|c|}
\hline $\begin{array}{l}\text { Factor limiting expression of yield } \\
\text { potential }\end{array}$ & $\begin{array}{l}\text { Crops in particular } \\
\text { concern }\end{array}$ & Adaptation measure(s) needed with reference \\
\hline $\begin{array}{l}\text { Enhanced development rate at ele- } \\
\text { vated temperatures in long days }\end{array}$ & $\begin{array}{l}\text { Seed and grain pro- } \\
\text { ducing determinate } \\
\text { crops (not pea) }\end{array}$ & $\begin{array}{l}\text { Plant breeding and selection for cultivars that can utilise the } \\
\text { climate change induced prolonged growing season thoroughly } \\
\text { without hastening too much in their development }{ }^{1,2}\end{array}$ \\
\hline
\end{tabular}

Water availability and distribution Spring sown crops within the growing season

Development of irrigation systems and breeding for improved water use efficiency ${ }^{2,3}$

Increasing risk for pest and disease All crops infestations

Extreme events

Overwintering success and fluctuation in winter conditions until cold winters become mild winters

Nutrient availability

All crops
Development of chemical and biological control agents, methods and alarm systems, breeding for disease resistance ${ }^{4,5,6}$

Alarm systems, development of cultivars with high yield stability, securing with sufficient farm resilience through crop diversity ${ }^{7,8}$

Autumn sown crops Breeding for improved overwintering capacity and avoiding introduction of cultivars not well adapted to northern conditions 9,10

Changes in fertiliser practices and possible introduction of split fertiliser use; efficient crop rotations and increasing use of legumes, breeding for improved nitrogen and phosphorus use efficiency ${ }^{11,12}$

\footnotetext{
${ }^{1}$ Peltonen-Sainio et al. (2007); ${ }^{2}$ Peltonen-Sainio et al. (2009d); ${ }^{3}$ Peltonen-Sainio et al. (2009c); Kaukoranta (1996); ${ }^{5}$ Carter et al. (1996); Hannukkala et al. (2007); ${ }^{7}$ Alexander et al. (2006); ${ }^{8}$ Klein Tank and Können (2003); ${ }^{9}$ Jylhä et al. (2008); ${ }^{10}$ Peltonen-Sainio et al. (2009a); ${ }^{11}$ Muurinen (2007); ${ }^{12}$ Muurinen et al. (2007)
} 


\section{Peltonen-Sainio et al. Climate change and Finnish field crop production}

seasons, indicating the necessity for comprehensive adaptation in order for climate change to benefit crop production.

Buckwheat is among the most potential pseudocereals, but it is very sensitive to frost and requires a minimum temperature of $+10^{\circ} \mathrm{C}$ for emergence (Montonen and Kontturi 1997). The current yield range is $900-1200 \mathrm{~kg} \mathrm{ha}^{-1}$. When growing conditions are favourable it can yield over 2000 $\mathrm{kg} \mathrm{ha}^{-1}$, but can fail completely under unfavourable conditions (Montonen and Kontturi 1997, Kontturi et al. 2004). According to FAO (2009) statistics it is grown on a large-scale in Russia (in $2006>1$ million ha), Lithuania (30 $000 \mathrm{ha}$ ) and Latvia (14 000 ha), with yields averaging in most cases 500 to 950 $\mathrm{kg} \mathrm{ha}^{-1}$.

Winter cereals are likely to replace spring cereals when their overwintering capacity is sufficient for a particular region. They are attractive because of their 1) higher yield potential, 2) better ability to avoid early summer drought induced yield losses (Peltonen-Sainio et al. 2009d), and 3) soil cover, reducing risk of erosion and nutrient leaching. Yield potential per se for winter wheat and rye is likely to increase considerably due to breeding and changes in growing conditions, and according to our estimations, potential yields of winter wheat would exceed those of spring wheat (Table 5). Furthermore, due to anticipated increase in severe problems with early summer drought, the gap between potential and achieved yields of winter and spring types would likely increase. At this time wheat is the only crop with both spring and winter cultivars in Finnish agriculture. According to averaged yield history (1985) of spring and winter wheat, shown in Tables 3 and 5, their yield potentials differ markedly; 2900-2600 $\mathrm{kg} \mathrm{ha}^{-1}$ for spring wheat and 5200-4900 $\mathrm{kg} \mathrm{ha}^{-1}$ for winter wheat at $60-63^{\circ} \mathrm{N}$. Although this is the only available example based on direct comparison between winter and spring types, in general, introduction of winter types into cultivation is likely to substantially shift yield levels. This will, however, happen in each region only when the primary limiting factor is overcome; the crop needs to successfully overwinter. The current common winter crops, winter rye and wheat, will later be accompanied by triticale, winter barley, and probably also winter oat.

Table 5. Estimated means for enhanced potential yields of winter wheat and rye in the case of successful overwintering and field pea in 30-year periods centred on 2025 and 2055 depending on latitude and compared with recent history (1971-2000, centered on 1985). Anticipated potential yields ( $\left.\mathrm{t} \mathrm{ha}^{-1}\right)$ dependent on ${ }^{\circ} \mathrm{Cd}$ are shown as B1 estimate - A2 estimate. Plant breeding achievements are included in estimations with expectation of pace of genetic yield gain being similar to 1971-2000. Effect of elevated $\mathrm{CO}_{2}$ on yields is ignored. At each latitude potential yields in western regions are slightly higher (ca. 3\%) than in eastern regions.

\begin{tabular}{|c|c|c|c|c|c|c|c|c|}
\hline \multirow[t]{2}{*}{ Crop } & \multirow[t]{2}{*}{ Time } & \multicolumn{7}{|c|}{ Latitude } \\
\hline & & $60^{\circ} \mathrm{N}$ & $61^{\circ} \mathrm{N}$ & $62^{\circ} \mathrm{N}$ & $63^{\circ} \mathrm{N}$ & $64^{\circ} \mathrm{N}$ & $65^{\circ} \mathrm{N}$ & $66^{\circ} \mathrm{N}$ \\
\hline \multirow[t]{3}{*}{ Winter wheat } & 1985 & 5.2 & 5.2 & 5.1 & 4.9 & . & . & $\cdot$ \\
\hline & 2025 & $7.1-7.1$ & $7.1-7.2$ & $7.0-7.0$ & $6.7-6.8$ & $6.6-6.6$ & . & . \\
\hline & 2055 & $9.0-9.2$ & $9.0-9.2$ & $8.8-9.0$ & $8.5-8.7$ & $8.3-8.5$ & $8.1-8.3$ & $7.9-8.1$ \\
\hline \multirow[t]{3}{*}{ Winter rye } & 1985 & 4.3 & 4.3 & 4.2 & 4.1 & 3.9 & 2.2 & 1.2 \\
\hline & 2025 & $6.6-6.6$ & $6.6-6.6$ & $6.4-6.4$ & $6.3-6.3$ & $6.2-6.2$ & $6.0-6.0$ & $5.3-5.3$ \\
\hline & 2055 & $9.1-9.2$ & $9.1-9.2$ & $8.9-9.1$ & $8.7-8.9$ & $8.5-8.7$ & $8.4-8.5$ & $8.2-8.3$ \\
\hline \multirow[t]{3}{*}{ Field pea } & 1985 & 4.4 & 4.4 & 4.1 & 3.7 & 2.8 & 1.4 & $\cdot$ \\
\hline & 2025 & $6.3-6.3$ & $6.3-6.3$ & $5.8-5.9$ & $5.4-5.4$ & $4.9-4.9$ & $4.5-4.5$ & 2.9-2.9 \\
\hline & 2055 & $7.9-8.3$ & $7.9-8.4$ & $7.4-7.9$ & $6.9-7.3$ & $6.3-6.8$ & $5.9-6.3$ & $5.3-5.7$ \\
\hline
\end{tabular}


Vol. 18 (2009): 171-190.

Due to lack of comprehensive experimentation in Finland, productivity of such novel crops can only be estimated according to current yields in Sweden and Denmark. In Sweden and Denmark the national record yields for triticale range from 5200 to $5400 \mathrm{~kg} \mathrm{ha}^{-1}$ (FAO 2009), which provides an estimate of future attainable yield. In Finnish experiments, yields of triticale exceeding $5000 \mathrm{~kg}$ $\mathrm{ha}^{-1}$ were recorded even at 800 to $1000^{\circ} \mathrm{Cd}$ growing seasons, emphasising the high yield potential of triticale when grown under milder winter conditions than currently pertain. On the other hand, in Denmark the yield gap between winter and spring barley was 1100,200 and $1400 \mathrm{~kg} \mathrm{ha}^{-1}$ during the last three years (Statistics Denmark 2009), while in UK the yield gap between winter and spring oat was 1200,1600 and $1700 \mathrm{~kg} \mathrm{ha}^{-1}$ in 2005, 2006 and 2007, respectively (Central Statistics Office Ireland 2009). As our yield potential estimations were only possible for spring barley and oat (Table 3), a shift from spring to winter types in the latter part of this century may result in additional yield benefit, which might compare with the present difference between these two types in these more southern countries.

Turnip rape and oilseed rape yield potentials are enhanced by a prolonged growing season. Contrary to the earlier situation where turnip rape yields exceeded those of oilseed rape, future climate warming will likely benefit oilseed rape more and hence, according to our estimations, reach turnip rape yields in the southernmost regions within the next ten years or so. By mid-century oilseed rape is set to out-yield turnip rape throughout the country, except northernmost Finland (Peltonen-Sainio et al. 2009b). This has happened in southern Sweden and Denmark, and winter types would gradually out-compete spring forms in Finland in the future. There has been no large-scale, modern cultivation of winter turnip rape and oilseed rape in Finland. Spring turnip rape has traditionally predominated due to its higher production stability and quality, but during the last couple of years the area under oilseed rape has increased from $1 \%$ to $12 \%$ of total rapeseed area (Peltonen-Sainio et al. 2007 and $2009 \mathrm{~b}$ ) and the trend continues. Contrary to the current situation in Finland, in Uppland in Swe- den, at comparable latitudes to southern Finland, winter types have been successfully adapted for cultivation. Record regional yields were produced in 2002 of over $3500 \mathrm{~kg} \mathrm{ha}^{-1}$ for winter oilseed rape, about $2500 \mathrm{~kg} \mathrm{ha}^{-1}$ for winter turnip rape, $2300 \mathrm{~kg}$ $\mathrm{ha}^{-1}$ for spring oilseed rape and only around 1500 $\mathrm{kg} \mathrm{ha}^{-1}$ for spring turnip rape (Svensk Raps 2009). However, in 2008 there were only 1300 hectares of spring turnip rape in Sweden and the crop seems set to vanish from cultivation within the near future. Similarly to the Swedish situation, under future Finnish conditions spring turnip rape will likely remain an important Brassica crop only in the northernmost growing regions, and it is likely to play an important role as a pioneer crop when new regions for Brassica production are developed. In the southernmost regions of Sweden, Skåne, the number of frost days was 50-100 and the length of the growing season up to 200 days in period 1961-1990 (Tveito et al. 2001). Record regional yields of winter oilseed rape (in 2008) were almost $4000 \mathrm{~kg} \mathrm{ha}^{-1}$ (Svensk Raps 2009). This indicates potential future yields in Finland with a changing climate. Similarly in Denmark, national oilseed rape yields approached $4000 \mathrm{~kg} \mathrm{ha}^{-1}$ in the most favourable years of the 2000s, while yields in the Baltic countries have remained modest (FAO 2009). Regardless of whether we anticipate our future yield of Brassica crops in Finland by comparing how conditions in the future would resemble those of southern Sweden and Denmark, or make statistical estimations (Table 6), oilseed rape is a typical "borderline crop", but is a high potential oil and protein-rich crop of the future.

Leguminous seed producing crops, field pea and faba bean are favoured by a prolonged growing season and their yields are expected to increase under future conditions as the current low accumulated temperature sums restrict yields. This is also evident when comparing present yields (1985) at different latitudes (Table 5). Similarly, yield responsiveness of field pea to increased growing season degree days was more marked than for other crops: $320 \mathrm{~kg} \mathrm{ha}^{-1}$ per $100{ }^{\circ} \mathrm{Cd}$ compared with less than $100 \mathrm{~kg} \mathrm{ha}^{-1}$ for spring cereals (data not shown). As a result of climate warming, it is expected that field pea yields (1985) recorded 


\section{Peltonen-Sainio et al. Climate change and Finnish field crop production}

Table 6. Estimated means for enhanced potential yields of spring turnip rape and oilseed rape in 30-year periods centred on 2025, 2055 and 2085 depending on latitude and compared with recent history (1971-2000, centered on 1985). Anticipated potential yields $\left(\mathrm{t} \mathrm{ha}^{-1}\right)$ dependent on ${ }^{\circ} \mathrm{Cd}$ are shown as B1 estimate $-\mathrm{A} 2$ estimate. Plant breeding achievements are included in estimations with expectation of pace of genetic yield gain being similar to 1971-2000. Effect of elevated $\mathrm{CO}_{2}$ on yields is ignored. At each latitude potential yields in western regions are $15-50 \%$ higher than in eastern regions. At the end of this century (2085) spring turnip rape and oilseed rape cultivars are not likely to be grown other than at the northernmost latitudes and hence, their yield potential is estimated only for those latitudes.

\begin{tabular}{|c|c|c|c|c|c|c|c|c|}
\hline \multirow[t]{2}{*}{ Spring sown crop } & \multirow[t]{2}{*}{ Time } & \multicolumn{7}{|c|}{ Latitude } \\
\hline & & $60^{\circ} \mathrm{N}$ & $61^{\circ} \mathrm{N}$ & $62^{\circ} \mathrm{N}$ & $63^{\circ} \mathrm{N}$ & $64^{\circ} \mathrm{N}$ & $65^{\circ} \mathrm{N}$ & $66^{\circ} \mathrm{N}$ \\
\hline \multirow[t]{4}{*}{ Turnip rape } & 1985 & 1.6 & 1.6 & 1.3 & 1.0 & 0.6 & 0.3 & . \\
\hline & 2025 & $3.1-3.1$ & $3.1-3.1$ & $2.7-2.7$ & $2.3-2.3$ & $1.9-1.9$ & $1.6-1.6$ & $0.9-0.9$ \\
\hline & 2055 & $4.7-5.2$ & $4.8-5.3$ & $4.3-4.8$ & $3.8-4.2$ & $3.3-3.7$ & $2.8-3.2$ & $2.3-2.7$ \\
\hline & 2085 & . & . & . & . & . & $4.4-6.1$ & $3.6-5.4$ \\
\hline \multirow[t]{4}{*}{ Oilseed rape } & 1985 & 1.0 & 1.0 & 0.8 & 0.4 & . & . & . \\
\hline & 2025 & $2.9-2.9$ & $2.9-3.0$ & $2.5-2.5$ & $2.0-2.0$ & $1.6-1.6$ & $1.0-1.0$ & $0.4-0.4$ \\
\hline & 2055 & $5.7-6.3$ & $5.8-6.5$ & $5.1-5.7$ & $4.3-4.9$ & $3.6-4.2$ & $3.0-3.6$ & $1.8-2.8$ \\
\hline & 2085 & . & & . & . & . & $6.0-8.9$ & $4.7-7.7$ \\
\hline
\end{tabular}

from the southernmost production region of Finland would be reached at up to $65^{\circ} \mathrm{N}$ by 2025 , while by 2055 the yield potential at $66^{\circ} \mathrm{N}$ would far exceed that currently reached at $60^{\circ} \mathrm{N}$. However, today's experimental yields at $60-62{ }^{\circ} \mathrm{N}$ are higher than the national record yields in Denmark $\left(4000 \mathrm{~kg} \mathrm{ha}^{-1}\right)$ and Sweden $\left(<3000 \mathrm{~kg} \mathrm{ha}^{-1}\right)$ (FAO 2009). While our experiments are conventionally managed, national yields always include organic production, thereby skewing the comparison. Faba bean experiments are too few to enable comprehensive comparisons of productivity between field pea and faba bean to be made. The short growing season confers no marked yield advantage for faba bean over field pea because there have been few years with accumulated degree days higher than the critical $1100{ }^{\circ} \mathrm{C}$ limit required by faba bean (data not shown). Nevertheless, both leguminous seed crops represent very interesting opportunities for future production systems of Finland, not least due to their nitrogen fixing capacity, but also as their expanded cultivation could contribute to improved self-sufficiency of crop-based feed protein production in the future.

\section{Conclusions}

The approach used has shown that climate warming offers new opportunities for Finnish grain and seed crop production, especially regarding 1) expansion of cultivation of current minor, "borderline crops", which are, however, valuable and attractive in rotations and for industry, such as oilseed rape, pea and faba bean, 2) expansion of current minor overwintering crops such as winter wheat and triticale, 3) introduction of novel overwintering cultivars of barley, oilseed rape and oat and, 4) considerable enhancement of yield potential of all crops currently grown in these northernmost European conditions, including our important major field crops. It is, however, important to note that it is not only the length of the physiologically effective growing 
Vol. 18 (2009): 171-190.

season that determines the regional suitability and yield potentials of common and novel crops. Realisation of anticipated, greatly increased yield potentials requires successful adaptation to the most critical production risks (Table 4). This approach only covered potential seed and grains crops, and forage maize, but there is potential for increased crop diversity in Finland. However, the predicted increased variability of growing conditions, more frequent weather extremes and outbreaks of pests and diseases, are likely to increase production risks and uncertainty. These might reduce farmer interest in growing new crops adapted to the world's northernmost growing conditions. It is also likely that even though there are likely to be marked differences among crops in their responses to climate induced changes in growing conditions, as well as in their adaptation processes and general success and potential, changes in global markets will drive farmer decision making and determine climate change adaptation strategies.

Acknowledgements. The authors are grateful to the numerous partners who participated in organising the MTT Official Cultivar Trials since 1970 and to the Finnish Meteorological Institute for climate change datasets provided for use in the ILMASOPU-project. The work was financed by the Finnish Ministry of Agriculture and Forestry, MTT Agrifood Research Finland and Raisio Ltd. as a part of an on-going consortium project entitled Adaptation of Finnish Agro-food Sector to Climate Change (ILMASOPU) for 2006-2009, which belongs to the National Climate Change Adaptation Program, ISTO.

\section{References}

Alexander, L.V., Zhang, X., Peterson, T.C., Caesar, J., Gleason, B., Klein Tank, A.M.G., Haylock, M., Collins, D., Trewin, B., Rahimzadeh, F., Tagipour, A., Rupa Kumar, K., Revadekar, J., Griffiths, G., Vincent, L., Stephenson, D.B., Burn, J., Aguilar, E., Brunet, M., Taylor, M., New, M., Zhai, P., Rusticucci, M. \& Vazquez-Aguirre, J.L. 2006. Global observed changes in daily climate extremes of temperature and precipitation. Journal of Geophysical Research 111, D05109, 22 p.

Aniszewski, T. 1988a. Initial development of three blue lupin (Lupinus angustifolius L.) varieties in northern Finland. Annales Agriculturae Fenniae 27: 141-151.
Aniszewski, T. 1988b. Environment, phenological development and dry matter formation of the blue lupin (Lupinus angustifolius L.) varieties in northern Finland. Acta Agriculturae Scandinavica 38: 303-316.

Aniszewski, T., Kupari, M.H. \& Leinonen, A.J. 2001. Seed number, seed size and seed diversity in Washington lupin (Lupinus polyphyllus Lindl.). Annals of Botany 87: 77-82.

Anon. 1999. Oats in a New Era. Semundo Limited, Cambridge, UK. 88 p.

Aronen, I. 2008. Sensitive phases in production and delivery processes and their impacts. In: Partanen, K. \& Niemeläinen, O. NJF Seminar 410: Risk Assessment of Global Agrifood Production Chains - NJF's 90 Year Jubilee Symposium, Helsinki, Finland. NJF Report 4, 7: 12-16.

Callaway, J.C. 2004. Hemp seed production in Finland. Journal of Industrial Hemp 9: 97-103.

Carter, T.R. 1998. Changes in the thermal growing season in Nordic countries during the past century and prospects for the future. Agricultural and Food Science in Finland 7: 161-179.

Carter, T.R. \& Saarikko, R.A. 1996. Estimating regional crop potential in Finland under a changing climate. Agricultural and Forest Meteorology 79: 301-313.

Carter, T.R., Parry, M.L. \& Porter, J.H. 1991. Climatic change and future agroclimatic potential in Europe. International Journal of Climatology 11: 251-2-69.

Carter, T.R., Saarikko, R.A. \& Niemi, K.J. 1996. Assessing the risks and uncertainties of regional crop potential under a changing climate in Finland. Agricultural and Food Science in Finland 5: 329-350.

Central Statistics Office Ireland 2009. Homepage of Central Statistics Office Ireland. Cited on $6^{\text {th }}$ July 2009. Update on $15^{\text {th }}$ September 2009. Available on the internet: http://www.cso.ie.

FAO 2009. Homepage of Food and Agriculture Organization of the United Nations. Cited on $6^{\text {th }}$ July 2009. Update on $23^{\text {rd }}$ June 2009. Available on the internet: http:// faostat.fao.org.

Finola 2009. Homepage of Finola ${ }^{\circledR}$ distributed by Elixi Oil Oy. Cited on $6^{\text {th }}$ July 2009. Update on $14^{\text {th }}$ July 2009. Available on the internet: www.finola.com.

Fronzek, S. \& Carter, T.R. 2007. Assessing uncertainties in climate change impacts on resource potential for Europe based on projections from RCMs and GCMs. Climatic Change 81: 357-371.

GAISMA 2009. Cited on $6^{\text {th }}$ July 2009. Available on the internet: http://www.gaisma.com.

Hakala, K. 1998. Growth and yield potential of spring wheat in a simulated changed climate with increased $\mathrm{CO}_{2}$ and higher temperature. European Journal of Agronomy 9: 41-52.

Hakala, K. \& Mela, T. 1996. The effects of prolonged exposure to elevated temperatures and elevated CO2 levels on the growth, yield and dry matter partitioning of fieldsown meadow fescue (Festuca pratensis, cv. Kalevi). Agricultural and Food Science in Finland 5: 285-298.

Hannukkala, A., Kaukoranta, T., Lehtinen, A. \& Rahkonen, A. 2007. Late-blight epidemics on potato in Finland, 1933-2002; increased and earlier occurrence of epidemics associated with climate change and lack of rotation. Plant Pathology 56: 167-176. 


\section{Peltonen-Sainio et al. Climate change and Finnish field crop production}

Hiivola, S.-L. 1966. Öljykasvitutkimukset kasvinjalostuslaitoksella 1942-1963. In: August Jäntti (ed.). Professori Otto Vallen juhlajulkaisu. Suomen Maataloustieteellisen Seuran Julkaisuja 107: 90-102. (In Finnish, summary in English).

Hofgaard, I.S., Vollsnes, A.V., Marum, P., Larsen, A. \& Tronsmo, A.M. 2003. Variation in resistance to different winter stress factors within a full-sib family of perennial ryegrass. Euphytica 134: 61-75.

Hömmö, L. \& Pulli, S. 1993. Winterhardiness of some winter wheat (Triticum aestivum), rye (Secale cereale), triticale (X Triticosecale) and winter barley (Hordeum vulgare) cultivars tested at six locations in Finland. Agricultural Science in Finland 2: 311-327.

IPCC 2007a. Summary for Policymakers. In: Climate Change 2007: Impacts, Adaptation and Vulnerability. Contribution of Working Group II to the Fourth Assessment Report of the Intergovernmental Panel on Climate Change, M.L. Parry, O.F. Canziani, J.P. Palutikof, P.J. van der Linden and C.E. Hanson, Eds., Cambridge University Press, Cambridge, UK, $16 \mathrm{p}$.

IPCC 2007b. Summary for Policymakers. In: Climate Change 2007: The Physical Science Basis. Contribution of Working Group I to the Fourth Assessment Report of the Intergovernmental Panel on Climate Change. Solomon, S., D. Qin, M. Manning, Z. Chen, M. Marquis, K.B. Averyt, M. Tignor \& H.L. Miller (eds.). Cambridge University Press, Cambridge, United Kingdom and New York, NY, USA, $18 \mathrm{p}$.

Jylhä, K., Tuomenvirta, H. \& Ruosteenoja, K. 2004. Climate change projections for Finland during the 21st century. Boreal Environment Research 9: 127-152.

Jylhä, K., Fronzek, S., Tuomenvirta, H., Carter, T.R. \& Ruosteenoja, K. 2008. Changes in frost, snow and Baltic sea ice by the end of the twenty-first century based on climate model projections for Europe. Climatic Change 86: 441-462.

Kaukoranta, T. 1996. Impact of global warming on potato late blight: risk, yield loss and control. Agricultural and Food Science in Finland 5: 311-326

Kaukoranta, T. \& Hakala, K. 2008. Impact of spring warming on sowing times of cereal, potato and sugar beet in Finland. Agricultural and Food Science 17: 165-176.

Kleemola, J. 1991. Effect of temperature on phasic development of spring wheat in northern growing conditions. Acta Agriculturae Scandinavica 41: 275-283.

Klein Tank, A.M.G. \& Wijngaard, J.B., et al., 2002. Daily dataset of 20th-century surface air temperature and precipitation series for the European Climate Assessment. International Journal of Climatology 22: 1441-1453.

Klein Tank, A.M.G. \& Können, G.P. 2003. Trends in indices of daily temperature and precipitation extremes in Europe, 1946-1999. Journal of Climate 16: 3665-3680.

Kontturi, M. 1979. The effect of weather on yield and development of spring wheat in Finland. Annales Agriculturae Fenniae 18: 263-274.

Kontturi, M., Keskitalo, M. \& Ketoja, E. 2004. Buckwheat cultivars in the North. In: Eds. Iva Faberová et al., Advances in buckwheat research: proceedings of the 9th International symposium on buckwheat held at the, Prague, Czech Republic. p 496-498.

Kurlovich, B. S., Hovinen, S., Hyovela, M., Heinanen, J. \& Kulakov, N. 2004. Possibility of selection and cultiva- tion of narrow-leafed lupin in Finland. In: Wild and cultivated lupins from the Tropics to the Poles. Proceedings of the 10th International Lupin Conference, Laugarvatn, Iceland. p 56-58.

Lääniste, P., Joudu, J., Eremeev, V. \& Mäeorg, E. 2008. Effect of sowing date and increasing sowing rates on plant density and yield of winter oilseed rape (Brassica napus L.) under Nordic climate conditions. Acta Agriculturae Scandinavica Section $B-$ Soil and Plant Science 58: 330-335.

Lindén, L., Palonen, P. \& Seppänen, M. 1999. Cold hardiness research on agricultural and horticultural crops in Finland. Agricultural and Food Science in Finland 8: 459-477.

Martin, J.H., Waldren, R.P. \& Stamp, D.L. 2006. Principles of field crop production, $4^{\text {th }}$ edition. Pearson Education, Inc. New Jersey, USA. 954 p.

Montonen, R. \& Kontturi, M. 1997. Tattarin viljelytekniikka. Maatalouden tutkimuskeskuksen julkaisuja. Sarja A 14: 51 p. (in Finnish, summary in English).

Muurinen, S. 2007. Nitrogen dynamics and nitrogen use efficiency of spring cereals under Finnish growing conditions. University of Helsinki, Department of Applied Biology, Section of Crop Husbandry 29: 38 p. Diss.: Helsinki: Helsingin yliopisto, 2007.

Muurinen, S., Kleemola, J. \& Peltonen-Sainio, P. 2007. Accumulation and translocation of $\mathrm{N}$ in spring cereal cultivars differing in NUE. Agronomy Journal 99: 441-449.

Nakicenovic N., Alcamo J., Davis G., de Vries B., Fenhann J., Gaffin S., Gregory K., Grübler A., Jung T.Y., Kram T., La Rovere E.L., Michaelis L., Mori S., Morita T., Pepper W., Pitcher H., Price L., Raihi K., Roehrl A., Rogner H.-H., Sankovski A., Schlesinger M., Shukla P., Smith S., Swart R., van Rooijen S., Victor N. \& Dadi Z., 2000. Emissions Scenarios. A Special Report of Working Group III of the Intergovernmental Panel on Climate Change. Cambridge University Press, 599 p.

Öfversten, J., Jauhiainen, L. \& Kangas, A. 2004. Contribution of new varieties to cereal yields in Finland between 1973 and 2003. The Journal of Agricultural Science 142: 281-287.

Olesen, J.E. \& Bindi, M. 2002. Consequences of climate change for European agricultural productivity, land use and policy. European Journal of Agronomy 16: 239262.

Olesen, J.E., Trnka, M., Kersebaum, K.C., Skjelvåg, A.O., Seguin, B., Peltonen-Sainio, P., Rossi, F., Kozyra, J. \& Micale, F. 2009. Impacts and adaptation of European crop production systems to climate change. European Journal of Agronomy, under revision.

Pahkala, K., Pahkala, E. \& Syrjälä, H. 2008. Northern limits to fiber hemp production in Europe. Journal of Industrial Hemp 13: 104-116.

Peltonen-Sainio, P., Jauhiainen, L. \& Hannukkala, A. 2007. Declining rapeseed yields in Finland: how, why and what next? The Journal of Agricultural Science 145: 587-598.

Peltonen-Sainio, P., Rajala, A., Känkänen, H. \& Hakala, K. 2009a. Improving farming systems in northern European conditions. In: V. O. Sadras and D. F. Calderini (eds.) Crop Physiology. Applications for Genetic Improvement and Agronomy. Elsevier, Amsterdam. pp. 71-97.

Peltonen-Sainio, P., Hakala, K., Jauhiainen, L. \& Ruos- 
Vol. 18 (2009): 171-190.

teenoja, K. 2009b. Comparing regional risks in producing turnip rape and oilseed rape - Impacts of climate change and breeding. Acta Agriculturae Scandinavica Section $B$ - Soil and Plant Science 59: 129-138.

Peltonen-Sainio, P., Jauhiainen, L., Hakala, K. \& Ruosteenoja, K. 2009c. Growth duration and phasing, distribution of precipitation and yielding capacity of spring cereals and rapeseed in chancing climate at high latitudes. Field Crops Research, submitted.

Peltonen-Sainio, P., Jauhiainen, L. \& Hakala, K. 2009d. Crop responses to precipitation and elevated temperatures in cool growing conditions at high latitudes according to long-term multi-location trials. Manuscript submitted.

Peltonen-Sainio, P., Jauhiainen, L. \& Laurila, I.P. 2009e. Cereal yield trends in northern European conditions: Changes in yield potential and its realisation. Field Crops Research 110: 85-90.

Rousi, A. 1997. Auringonkukasta viiniköynnökseen. Ravintokasvit. WSOY, Porvoo, Finland. 390 p. ISBN 9510-21295-4 (in Finnish).

Saarikko, R.A. 2000. Applying a site based crop model to estimate regional yields under current and changed climates. Ecological Modelling 131: 191-206.

Saarikko, R.A. \& Carter, T.R. 1996. Estimating the development and regional thermal suitability of spring wheat in Finland under climatic warming. Climate Research
7: $243-252$.

Serenius, M., Huusela-Veistola, E., Avikainen, H., Pahkala, K. \& Laine, A. 2005. Effects of sowing time on pink snow mold, leaf rust and winter damage in winter rye varieties in Finland. Agricultural and Food Science 14: 362-376.

Smartt, J. \& Simmonds, N.W. 1995. Evolution of Crop Plants. John Wiley \& Sons, Inc., New York, USA. 531 p. ISBN 0-582-08643-4

Statistics Denmark 2009. Homepage of Statistics Denmark. Cited on $6^{\text {th }}$ July 2009 . Update on $17^{\text {th }}$ December 2008. Available on the internet: http://www.dst.dk/ HomeUK/Statistics.

Svensk Raps 2009. Homepage of Svensk Raps. Cited on $6^{\text {th }}$ July 2009. Update on $16^{\text {th }}$ September 2009. Available on the internet: http://www.svenskraps.se.

Tveito, O.E., Forland, E.J., Alexandersson, H., Drebs, A., Jónsson, T., Tuomenvirta, H. \& Vaarby Laursen, E. 2001. Nordic climate maps. KLIMA report 6/2001.

Velicka R., Marcinkeviciene, A., Raudonius, S. \& Rimkeviciene, M. 2006. Integrated evaluation of rape readiness for overwintering. Acta Agriculturae Scandinavica Section B - Soil and Plant Science 56: 110-116.

Venäläinen, A, Tuomenvirta, H., Pirinen, P. \& Drebs, A. 2005. A basic Finnish climate data set 1961-2000 - Description and illustrations. Reports 2005:5. Finnish Meteorological Institute, Helsinki, Finland.

\title{
SELOSTUS
}

\section{Kasvukauden pitenemisen vaikutukset alueellisiin viljelymahdollisuuksiin ja tuotan- tokykyyn Suomessa ilmaston lämmetessä}

\author{
Pirjo Peltonen-Sainio, Lauri Jauhiainen, Kaija Hakala ja Hannu Ojanen \\ MTT Kasvintuotannon tutkimus ja Palveluyksikkö
}

Ilmaston muutos tuo mukanaan uusia mahdollisuuksia mutta myös haasteita suomalaiselle kasvinviljelylle. Ilmaston lämpenemisen myötä kasvien hyödynnettävissä oleva kasvukausi pitenee ja talvien leudontuessa edellytykset syysmuotojen viljelyyn paranevat. Tutkimuksen tarkoituksena oli arvioida kahden eri päästöskenaarion perusteella (IPCC SRES: A2 ei hillintätoimia, B1 kaikki hillintätoimet käyttöön), millä aikajänteellä nykyisten viljelykasvien viljelyalueet voivat laajentua, miten aivan uudet tai meillä vielä vähän viljellyt, mutta lähialueillamme tärkeät, kasvit voivat yleistyä. Lisäksi tavoitteena oli arvioida eri viljelykasvien satopotentiaalissa tapahtuvia muutoksia ottamalla huomioon kasvukauden pitenemisen sekä ennakoiden kasvien satoisuusjalostuksen mahdollisuuksia. Laskelmat tehtiin A2- ja B1-skenaarioissa ja ne perustuivat Ilmatieteen laitoksen osana ILMASOPUhanketta tuottaman 19 ilmastomallin konsensusennusteeseen lämpötilojen muutoksista talvella ja kasvukaudella kolmessa tulevaisuuden ajankohdassa: 2025, 2055 ja 2085 ( \pm 15 vuotta). Muutoksia peilattiin lähimenneisyyteen (1971-2000). Eri viljelykasvien alueellisen viljeltävyyden arvioinnissa kiinnitettiin huomioita siihen, mikä osa termisestä kasvukaudesta voidaan hyödyntää viljelyssä (lähtien kylvöistä ja päätyen korjuuseen) sekä 


\section{Peltonen-Sainio et al. Climate change and Finnish field crop production}

minkä suuruinen termisen talven kestossa tapahtuva muutos tulee todennäköisesti olemaan. Tutkimus keskittyi siemensatokasveihin.

Tutkimuksen mukaan ilmaston lämpenemisen myötä nykyisiä päätuotantokasveja on mahdollista viljellä yhä pohjoisempana ja myös niiden pohjoisen viljelyn satopotentiaalit kasvavat merkittävästi. Tutkimuksen tuloksena arvioitiin, että parin vuosikymmenen kuluttua esimerkiksi nykyisiä Etelä-Suomelle tyypillisiä ohrasatoja voidaan tuottaa jopa Oulua myöten. Lisäksi vielä nykyään vähän viljeltyjen kasvilajien, kuten rapsin, herneen ja härkäpavun, tuotanto voi muuttua Suomessa laajamittaiseksi. Kasvilajien menestymisedellytysten paranemisen lisäksi niiden laajempaa viljelyä tukee niiden lisääntyvä sadontuottokyky, hyödyllisyys viljelykierroissa sekä erityisesti palkoviljojen typpiomavaraisuus. Näillä tuotantokasveilla tulee olemaan merkittävä rooli kotimaisen rehuvalkuaisen omavaraisuuden parantamisessa. Joidenkin tuotantokasvilajien viljelyn laajentaminen edellyttää kuitenkin myös teollisuuden valmiutta käyttää niitä prosesseissaan ja jalosteissaan. Myös käynnissä olevat tai helposti aktivoitavat jalostusohjelmat luovat osaltaan edellytyksiä uusien tai nykyään harvinaisten kasvilajien viljelylle. Lähivuosikymmenien aikana talvien leudontuessa, nykyisin vähän viljellyistä tuotantokasveista syysvehnä ja ruisvehnä yleistyvät todennäköisesti ensimmäisinä. Niiden kilpailuetu paranee merkittävästi johtuen niiden hyvästä sadontuottokyvystä. Viljelykasvien syysmuodot ovat tulevaisuudessa tärkeitä myös talviaikaisen kasvipeitteisyyden ansiosta, sillä tulevaisuudessa eroosio- ja huuhtoumariskit kasvavat syys- ja talvisateiden yleistyessä ja talvien leudontuessa. Kun Suomen kylmät talvet leudontuvat pysyvästi ja alkavat muistuttaa Etelä-Ruotsin, Tanskan ja Skotlannin nykyisiä talvia - ehkä noin kuluvan vuosisadan jälkipuoliskolla, näillä alueilla laajasti viljellyt syysrapsi, -ohra ja -kaura todennäköisesti yleistyvät myös Suomessa. Kuluvalla vuosikymmenellä syysmuodot ovat edellä mainituilla alueilla tuottaneet tyypillisesti $1000 \mathrm{~kg} \mathrm{ha}^{-1}$ enemmän satoa kuin vastaavat kevätmuodot. Myös muiden nykyviljelyssämme alihyödynnettyjen lajien, kuten tattarin, pellavan, hampun, auringonkukan ja lupiinin viljelyedellytykset paranevat kasvukauden pidetessä. Uusista lajeista säilörehuksi kasvatettavan maissin viljely onnistuu tulevaisuudessa laajoilla alueilla Etelä-Suomea, vaikkakin kohtuullisin riskein vasta vuosisadan loppupuolella - jyvämaissin ei ilmeisesti vielä silloinkaan.

Tehty katsaus perustuu viljelykasvien kasvupotentiaalin arviointiin. On kuitenkin huomattava, että peltoviljelykasviemme tuotantokyvyn merkittävä parantuminen edellyttää ilmastonmuutoksen vahvistamien, tuotantoa rajoittavien keskeisimpien haasteiden ratkaisemista sekä näihin tähtäävien ennakoivien sopeutumisstrategioiden suunnittelua ja toimeenpanoa. Tekemämme viljelykasvien tulevaisuuden menestymisedellytysarvioinnin perusteella peltojemme viljelykasvilajisto voi tulevaisuudessa olla merkittävästi nykyistä monimuotoisempi. Monien tuotantokasvien viljelyn laajenemismahdollisuus ja satoisuuden oletettu merkittäväkin lisääntyminen eivät kuitenkaan yksinään ratkaise sitä, miltä peltoviljelymme tulee tällä vuosisadalla näyttämään. Maataloustuotteiden markkinoilla, hinnoilla ja maataloutta koskevilla poliittisilla päätöksillä on myös jatkossa erittäin suuri vaikutus viljelijän tekemiin viljelykasvivalintoihin. 